\title{
PENINJAUAN KEMBALI TERHADAP PUTUSAN \\ PENGADILAN YANG TELAH MEMPEROLEH KEKUATAN \\ HUKUM TETAP DALAM PERKARA PERDATA
}

\section{Winarno Adi Gunawan}

Abstrak

The peninjauan kembali (revision) under Indonesian procedure law system is as an extra ordinary efforts to against the supreme court decisions. Revision is applicable to the permanent decision by involved party that ought to filling the sue to the Supreme Court (Mahkamah Agung-RI). Based on law number 4 year 2004 has stipulated condition on the revision is under circumstance on any situation under article 23 section 1 which ought to under law provisions. The author here notes that any possibly impediment appears will not technically happen in practice later. Oftenly in revision implementations the lack or weakness does exist by the applicant side's. The mostly be deficient in the relevance's legal application to be considered upon Supreme Court.

Kata Kunci : hukum acara perdata, peninjauan kembali, hubungan hukum. kedudukan hukum. itikad baik.

\section{Pendahuluan}

Salah satu unsur dalam tujuan pembangunan nasional yang diamanatkan Garis garis Besar Haluan Negara adalah masyarakat adil dan makmur berdasarkan Pancasila dalam wadah negara kesatuan Republik Indonesia yang merdeka, berdaulat, bersatu, dan berkedaulatan rakyat dalam suasana perikehidupan bangsa yang sejahtera, aman, tenteram, dan tertib. Suasana perikehidupan tersebut di atas merupakan bagian dari gambaran terhadap tata kehidupan bangsa Indonesia yang dicita-citakan perwujudannya melalui rangkaian upaya dan kegiatan pembangunan yang berlanjut dan berkesinambungan. Namun demikian pengalaman dalam kehidupan bernegara dan berbangsa sejak kemerdekaan menunjukkan, bahwa usaha untuk mewujudkan perikehidupan seperti itu sangat dipengaruhi oleh berbagai hal yang saling berkait satu dengan lainnya.

Cita tentang keadilan, kebenaran, kepastian hukum, dan ketertiban sistem serta penyelenggaraan hukum merupakan hal yang mempengaruhi tumbuhnya suasana perikehidupan sebagaimana dimaksudkan di atas. 
Seperti kita ketahui bahwa negara Indonesia adalah negara hukum, untuk mengatur tata tertib dari suatu negara tersebut, maka dibuatlah suatu peraturan. Sedangkan peraturan itu sendiri terdiri dari peraturan tertulis dan tidak tertulis, yang mempunyai sanksi yang tegas terhadap pelanggarnya. Hukum ada bukan semata-mata sebagai pedoman untuk dibaca, dilihat atau diketahui saja melainkan sebagai pedoman untuk ditaati, tetapi kenyataannya masih sering terjadi pelanggaran hukum di dalam masyarakat, khususnya hukum perdata. Akibat dari pelanggaran itu dapat merugikan pihak lain tentunya pihak yang merasa dirugikan hak atau kepentingannya, Mereka bisa menuntut kebenaran dan keadilan untuk mempertahankan haknya tersebut maka terjadilah sengketa dalam pengadilan. Apabila dalam sengketa peradilan tingkat pertama ada pihak yang tidak puas, maka dapat mengajukan banding ke pengadilan tinggi dan apabila putusan dari pengadilan tingkat pertama dan putusan dari tingkat banding masih ada pihak yang tidak puas, maka bisa menggunakan upaya hukum kasasi.

Sistem peradilan di Indonesia mengenal dua tingkat yaitu peradilan tingkat pertama (pengadilan negeri) dan pengadilan tingkat banding (pengadilan tinggi), serta kasasi, Pemeriksaan perkara pada tingkat pertama merupakan pemeriksaan terhadap seluruh permasalahan atau duduk perkaranya, begitu juga pemeriksaan pada tingkat banding. Sedangkan pemeriksaan tingkat kasasi adalah pemeriksaan tentang penerapan hukumnya serta pemeriksaan hanya terbatas pada apa yang dimintakan kasasi.

Tujuan utama pemeriksaan tingkat banding, untuk mengoreksi dan meluruskan segala kesalahan dan kekeliruan penerapan hukum, tata cara mangadili, penilaian fakta dan pembuktian. Pembuktian itu diperlukan karena adanya bantahan atau penyangkalan dari pihak lawan tentang apa yang digugatan,atau untuk membenarkan suatu hak. ${ }^{\prime}$

Pengertian pembuktian menurut Prof. Sudikno Mertokusumo adalah cara meyakinkan hakim akan kebenaran peristiwa yang sebenamya. Karena kebenaran peristiwa inilah yang akan menjadi dasar bagi hakim yang memeriksa perkara yang bersangkutan guna memberi kepastian tentang kebenaran peristiwa yang diajukan. ${ }^{2}$

' Abdul Kadir Muhammad. "Hukum Acara Perdata Indonesia”. (Bandung: Penerbit Alumni, 1986). hal. 131.

${ }^{2}$ Sudikno Mertokusumo. "Hukum Acara Perdata ". (Yogyakarta: Liberty. 1988), hal.

101. 
Peninjauan Kembali merupakan upaya hukum luar biasa yang diberikan kepada kepada seseorang untuk dalam suatu hal tertentu melawan keputusan hakim. ${ }^{3}$ Upaya hukum Peninjauan Kembali dimungkinkan terhadap putusan pengadilan yang telah memperoleh kekuatan hukum tetap dalam pekara perdata oleh pihak-pihak yang berkepentingan kepada Mahkamah Agung.

Pada Prinsipnya suatu putusan hakim yang telah mempunyai kekuatan hukum tetap tidak dapat ditarik kembali dan harus dianggap telah terbukti kebenarannya namun masih juga diberikan kesempatan untuk hal-hal tertentu dan atas dasar yang kuat, putusan hakim tersebut diperiksa kembali. Apabila terdapat suatu putusan hakim tidak ada lagi kemungkinan melawan ( verzet ) atau untuk mohon banding atau kasasi, maka putusan itu menjadi pasti atau tetap dan putusan itu telah memperoleh kekuatan yang pasti, yang mengikat. Kekuatan yang mengikat ini adalah Suatu kemestian yang praktis berhubungan dengan tujuan acara perdata yaitu untuk menentukan bagaimana pada akhimya hubungan hukum antara kedua belah pihak.

Peninjauan Kembali merupakan upaya hukum terhadap putusan tingkat terakhir dan putusan yang dijatuhkan diluar hadir tergugat (Verstek). Dan yang tidak lagi terbuka kemungkinan untuk mengajukan perlawanan.

Sedangkan istilah Peninjauan Kembali itu sendiri dipakai dalam Undang-Undang No.4 tahun 2004 Pasal 23 ayat (1) tentang KetentuanKetentuan Pokok Kekuasan Kehakiman yang secara jelas menerangkan sebagai berikut:

\section{Terhadap putusan Pengadilan yang telah mempunyai kekuatan hukum tetap, pihak-pihak yang bersangkutan dapat megajukan Peninjauan Kembali kepada Mahkamah Agung, apabila terdapat hal atau keadaan tertentu yang ditentukan dalam Undang-undang.}

Dari ketentuan tersebut di atas dapat diterangkan bahwa apabila terdapat keadaan keadaan yang tertentu yang telah ditentukan oleh undangundang dapat dimintakan peninjauan kembali.

Permohonan peninjauan kembali terhadap putusan perkara perdata yang telah memperoleh kekuatan hukum tetap hanya dapat diajukan berdasarkan alasan yang ada dalam Undang-Undang No. 14 tahun 1985 Pasal 67 yang berbunyi:

${ }^{3}$ Retno Wulan Sutantio, dan Iskandar Uripkarta Winata, "Hukum Acara Perdata dalam Teori dan Praktek", (Bandung: Penerbit Alumni, 1983), hal. 121. 
a. Apabila putusan didasarkan pada suatu kebohongan atau tipu muslihat pihak lawan yang diketahui setelah perkaranya diputus oleh hakim yang di nyatakan palsu.

b. Apabila perkaranya yang setelah di putus ditemukan bukti-bukti yang bersifat menentukan yang pada waktu diperiksa tidak ditemukan.

c. Apabila telah di kabulkan suatu hal yang tidak dituntut atau lebih dari pada yang dituntut.

d. Apabila dalam suatu putusan terdapat kekhilafan hakim atau suatu kekeliruan yang nyata.

Namun di dalam pelaksanaan peninjauan kembali itu ada permasalahan yang mengakibatkan permohonan peninjauan kembali tidak diterima karena tidak memenuhi syarat. Masalah-masalah tersebut disebabkan karena:

1. Permohonan peninjauan kembali telah melampaui tenggang atau jangka waktu yang telah ditentukan.

2. Hal-hal yang dikemukakan pemohon peninjauan kembali bukan merupakan alas an peninjauan kembali sebagaimana dimaksud dalam Undang-Undang No. 14 tahun 1985.

Suatu putusan hakim itu tidak luput dari kekeliruan atau kekhilafan, dan tidak mustahil bersifat memihak. Maka oleh karena itu demi kebenaran dan keadilan setiap putusan hakim perlu dimungkinkan untuk diperiksa ulang, agar kekeliruan atau kekhilafan yang terjadi pada putusan dapat diperbaiki. Bagi setiap putusan hakim pada umumnya tersedia upaya hukum yaitu upaya atau alat untuk mencegah atau memperbaiki kekeliruan dalam suatu putusan.

Suatu putusan memperoleh kekuatan hukum yang pasti apabila tidak tersedia lagi upaya hukum biasa. Untuk putusan-putusan yang telah memperoleh kekuatan hukum tetap tersedia upaya hukum istimewa. Upaya hukum istimewa hanya diperbolehkan dalam hal hal tertentu yang disebut undang-undang saja.

Oleh karena itu putusan hakim yang berkekuatan hukum tetap tidak dapat diganggu gugat artinya sudah tertutup kesempatan menggunakan upaya hukum biasa, karena putusan tersebut sifatnya mengikat (Bin den dekracht) seperti mengikat dari putusan itu yaitu bertujuan untuk menetapkan suatu hasil hubungan antara para pihak yang berperkara atau menetapkan suatu keadaan hukum tertentu. 


\section{Permasalahan}

Berdasarkan uraian dalam penjelasan Peninjauan kembali terhadap putusan pengadilan yang telah memperoleh kekuatan hukum tetap dimuka, dapat disampaikan bahwa dalam prespektif hukum peninjauan kembali merupakan hubungan hukum yang lazim dan penting bagi pelaksanaan pemenuhan kebutuhan hidup masyarakat luas. Adanya berbagai permasalahan didalam putusan peninjauan kembali yang terjadi kiranya patut dijelaskan secara kerangka hukum yang berlaku. Sehubungan dengan permasalahan yang menjadi focus artikel ini, penulis akan menjelaskan permasalah sebagai berikut:

1. Bagaimana prosedur pengajuan upaya hukum peninjauan kembali?

2. Apa pertimbangan hakim di dalam putusan yang telah memperoleh kekutan hukum tetap?

3. Apa Problem atau hambatan apa yang terjadi dalam proses peninjauan kembali terhadap putusan yang telah memperoleh kekuatan hukum tetap?

\section{Pembahasan}

\section{A. Tinjauan Tentang Peninjauan Kembali}

Peninjauan Kembali merupakan putusan yang dijatuhkaa dalam tingkat terakhir dan putusan yang dijatuhkan diluar hadir tergugat (verstek) dan yang tidak lagi terbuka kemungkinan untuk mengajukan perlawanan dapat ditinjau kembali atau permohonan orang yang menjadi salah satu pihak didalam perkara yang harus diputus dan dimintakan Peninjauan kembali.

Menurut Abdul Kadir Muhammad, SH, Walaupun putusan hakim itu telah selesai dilaksanakan, masih ada kemungkinan untuk melakukan permohonan kasasi, apabila ternyata ada alasan untuk itu dan dirasakan tidak adil jika terus berpegang pada putusan semacam itu. Peninjauan Kembali itu bukanlah menghilangkan kepastian hukum dari putusan hakim, melaikan justru untuk mempertahankan keadilan itu sendiri dan memberikan kepastian hukum pada perbuatan yang adil. Peninjauan Kembali bersifat insidentil saja, terus menerus, tidak selalu ditemukan mungkin dalam seribu perkara yang diputus hakim yang telah memperoleh kekuatan hukum yang tetap, muncullah satu 
perkara yang ditemukan oleh yang berkepentingan dengan alasannya bahwa putusan itu perlu dilakukan Peninjauan Kembali ${ }^{4}$

Permohonan Peninjauan Kembali dapat dicabut kembali selama belum diputus dan hanya dapat diajukan satu kali saja. Selanjutnya dalam waktu 14 hari setelah Ketua Pengadilan Negeri yang memutus perkara dalam tingkat pertama menerima permohonan Peninjauan Kembali maka panitera menggunakan salinan permohonan kepada pihak lawan.

Sedangkan Istilah Peninjauan Kembali, diatur dalam Ayat (1) Undang-undang Nomor 4 Tahun 2004 yang menerangkan:

"Apabila terdapat hal-hal atau keadaan-keadaan yang ditentukan Undang-undang, terhadap putusan pengadilan yang telah memperoleh kekuatan hukum tetap dapat dimintakan Peninjauan Kembali kepada Mahkamah Agung"

Dari ketentuan tersebut diatas dapat diterangkan bahwa permohonan Peninjauan Kembali ditujukan baik terhadap putusan perkara pidana maupun terhadap putusan perkara perdata dan bahwa permohonan itu harus ditujukan kepada Mahkamah Agung.

Alasan yang menjadi dasar untuk melakukan Peninjauan Kembali diatur dalam Undang-undang Nomor 14 Tahun 1985 Pasal 67, karena Peninjauan Kembali hanya dapat diterima berdasarkan alasan-alasan tersebut. Alasan-alasan tersebut yaitu :

1) Apabila putusan didasarkan pada suatu kebohongan atau tipu muslihat pihak lawan yang diketahui setelah perkaranya diputus oleh hakim yang dinyatakan palsu;

2) Apabila perkara yang setelah diputus ditemukan bukti-bukti yang bersifat menentukan yang pada waktu diperiksa tidak ditemukan;

3) Apabila telah dikabulkan suatu hal yang tidak dituntut atau lebih dari yang dituntut;

4) Apabila suatu putusan terdapat kekhilafan hakim atau suatu kekeliruan yang nyata.

\footnotetext{
${ }^{4}$ Abdul Kadir Muhammad. Op. Cit., hal. 102.
} 
Alasan-alasan tersebut merupakan syarat dalam mengajukan permohonan dalam Peninjauan Kembali. Apabila didalam mengajukan permohonan peninjauan kembali tidak ada salah satu alasan tersebut diatas maka permohonan akan ditolak.

Bahwa Mahkamah Agung dalam memutus suatu perkara peninjauan kembali juga berpegang pada syarat atau alasan peninjauan kembali, itu tidak ada salah satu alasan yang membuktikan, maka Mahkamah Agung tidak menerima peninjauan kembali.

Adapun syarat-syarat yang memungkinkan untuk mengajukan permohonan Peninjauan Kembali adalah :

1. Putusan pengadilan yang telah memperoleh kekuatan hukum tetap.

Dalam perkara perdata putusan yang telah memperoleh kekuatan hukum tetap tidak dapat diganggu gugat artinya sudah tertutup kemungkinan untuk menggunakan upaya hukum biasa, karena putusan tersebut sifatnya mengikat.

2. Alasan-alasan Peninajaun Kembali.

Didalam mengajukan permohonan Peninjauan Kembali harus ada alasan-alasan yang menyebabkan Peninjauan Kembali.

Proses Peninjauan Kembali dimulai dengan diterimanya permohonan peninjauan kembali secara tertulis atau dengan lisan di Panitera Pengadilan Negeri yang pernah memutus perkaranya dalam tingkat pertama. Untuk peninjauan kembali permohonan dikenakan pembayaran biaya perkara yang dibayarnya ketika memasukan permohonannya di kepaniteraan. Untuk penerimaan permohonan Peninjauan Kembali serta biaya perkara itu panitera memberikan tanda penerimaan dan biaya itu. Tanggal penerimaan permohonan ini penting untuk menghitung tenggang waktu pengajuan kembali.

Setelah Pengadilan Negeri menerima suatu permohonan Peninjauan Kembali, maka panitera secepatnya memberikan atau mengirimkan salinan permohonan kepada pihak lawan dari pemohon. Pihak lawan yang menerima salinan permohonan Peninjauan Kembali dapat mengajukan jawabannya setelah diterimanya tuntutan permohonan peninjauan kembali.

Surat jawaban diserahkan atau dikirimkan Kepada Pengadilan Negeri tersebut dan pada surat jawaban tersebut oleh panitera dibubuhi cap yang berisi hari serta tanggal diterimanya jawaban tersebut, yang turunannya disampaikan atau dikirimkan kepada pemohon peninjauan kembali untuk dimaklum seperlunya. Kemudian permohonan jawaban atas permohonan serta surat-surat bukti dan bahan bukti lain kalau ada, 
lengkap dengan berkas perkara beserta biaya perkara diteruskan atau dikirimkan ke Mahkamah Agung dengan cara tercepat dan teraman.

Setelah seluruh berkas perkara diterima di Mahkamah Agung maka diadakan regestrasi dalam buku daftar perkara untuk itu dan sesudah itu diadakan penelitian apakah syarat-syarat kelengkapan berkas dipenuhi. Atas penerimaan pengiriman berkas itu direktorat atau bidang perdata Kepaniteraan Mahkamah Agung mengirimkan tanda terima Kepada Pengadilan Negeri yang bersangkutan dan kepada pihak-pihak turunannya.

Ketua Mahkamah Agung menentukan hakim-hakim yang membentuk suatu majelis untuk memeriksa dan memutus perkara permohonan Peninjauan Kembali. Apabila putusan yang dimohonkan peninjauan kembali itu adalah putusan Mahkamah Agung, maka hakim-hakim yang ditunjuk itu tidak terdiri atas hakim-hakim yang pernah mengadili perkara yang putusannya dimohon untuk ditinjau kembali. Ketentuan mengenai pembatalan ditunjukan terhadap peninjauan kembali yang dikabulkan berdasarkan alasan dan pertentangan putusan-putusan.

Setiap putusan pengadilan haras ditandatangani oleh Ketua, Hakim anggota dan Panitera kalau ketua sidang tidak dapat menandatangani putusan, maka hal itu akan dilakukan oleh hakim anggota yang ikut serta memeriksa. Sedangkan panitera yang berhalangan untuk menandatangani maka hal itu haras dinyatakan dengan tegas dalam berita acara.

Mahkamah Agung mempunyai kewenangan untuk:

a. mengadili pada tingkat kasasi terhadap putusan yang diberikan pada tingkat terakhir oleh pengadilan di semua lingkungan peradilan yang berada di bawah Mahkamah Agung;

b. menguji peraturan perundang-undangan di bawah undangundang terhadap undang-undang; dan

c. kewenangan lainnya yang diberikan undang-undang.

Dalam kaitannya dengan permohonan Peninjauan Kembali itu maka putusan Mahkamah Agung dapat dibedakan atas :

1) Putusan yang dinyatakan permohonaa peninjauan kembali tidak dapat diterima,

2) Putusan yang menolak,

3) Putusan yang mengabulkan permohonan peninjauan kembali.

Suatu permohonan Peninjauan Kembali tidak dapat diterima apabila: 
1) Permohonan diajukan tidak pada Mahkamah Agung;

2) Permohonan ditujukan kepada orang yang tidak merupakan pihak dalam perkara semula;

3) Permohonan tidak didasarkan pada alasan-alasan sebagai mana dimaksud dalam pasal 67 Undang-undang Nomor 14 Tahun 1985;

4) Diajukan terhadap putusan yang belum mendapat kekuatan hukum tetap;

5) Diajukan oleh seorang wakil tanpa Surat kuasa.

Apabila Mahkamah Agung mengabulkan suatu permohonan peninjauan kembali, Mahkamah Agung memandang permohonan peninjauan kembali itu dan selanjutnya memeriksa dan memutus sendiri perkaranya.

Apabila Mahkamah Agung memandang permohonan Peninjauan Kembali tidak beralasan, maka Mahkamah Agung menolak permohonan Peninjauan Kembali. Keputusan Mahkamah Agung diucapkan dimuka umum tanpa dihadiri para pihak yang memohon peninjauan kembali dan yang terhadapnya diajukan permohonan Peninjauan Kembali.

Suatu permohonan Peninjauan Kembali ditolak, apabila Mahkamah Agung berpendapat tidak membenarkannya. Permohonan itu tidak didukung oleh fakta atau keadaan yang mendukung alasan yang menjadi dasar permohonan peninjauan kembali. Dalam hal Mahkamah Agung menolak permohonan peninjauan kembali, maka tetap berlaku putusan semula yang dimohonkan Peninjauan Kembali.

Apabila Mahkamah Agung membenarkan alasan pemohon, Mahkamah Agung mengabulkan permohonan peninjauan Kembali dan membatalkan putusan-putusan yang atasnya dimohonkan Peninjauan Kembali itu. Selanjutnya Mahkamah Agung memeriksa serta memutus sendiri perkaranya. Pembatalan putusan semula yang atasnya dimohon Peninjauan Kembali dapat mengenai seluruh bagian atau sebagian saja dari putusan.

\section{B. Tinjauan Tentang Putusan}

Dalam suatu perkara perdata diantara pihak, maka perlu adanya suatu pemyataan yang dapat memberikan suatu keputusan guna mengakhiri suatu sengketa. Ada tiga macam jenis putusan yaitu: ${ }^{5}$ 
1. Putusan Declaratoir adalah putusan yang bersifat menerangkan, menegaskan suatu keadaan hukum semata-mata;

2. Putusan Constitutif adalah putusan yang meniadakan suatu keadaan hukum atau menimbulkan suatu keadaan hukum yang baru;

3. Putusan Condemnatoir adalah putusan yang berisi tentang penghukuman.

Menurut Lilik Mulyadi SH, Putusan adalah putusan yang di ucapkan oleh hakim karena jabatannya dalam persidangan perkara perdata yang terbuka untuk umum setelah melalui proses dan prosedural Hukum Acara Perdata, pada umumnya dibuat dalam bentuk tertulis dengan tujuan menyelesaikan dan mengakhiri perkara perdata. ${ }^{6}$

Menurut Riduan Syahrani SH, Putusan adalah pemyataan hakim yang diucapkan pada sidang pengadailan yang terbuka untuk umum, untuk menyelesaikan atau mengakhiri perkara perdata. ${ }^{7}$ Arti dari putusan itu sendiri adalah Hasil kesimpulan dari sesuatu yang telah dipertimbangkan dan dinilai dengan semasak-masaknya yang dapat berbentuk tertulis ataupun lisan. ${ }^{8}$

Jadi pada garis besarnya hakim dalam menjatuhkan putusannya untuk mengakhiri sengketa perdata yang terjadi antara pihak tergugat dan penggugat, dengan dijatuhkan putusan hal ini memberikan konsekuensi kepada hakim agar isi putusannya harus dapat memenuhi rasa keadilan bagi para pihak yang bersangkutan.

A pabila terdapat suatu putusan hakim, tidak ada lagi kemungkinan untuk melawan atau untuk mohon banding ataupun kasasi, maka putusan itu mempunyai kekuatan hukum yang pasti atau tetap. Dalam bahasa latin disebut dengan "Resjudi cata proveritate habetur". Artinya putusan yang pasti dengan sendirinya mempunyai kekuatan yang mengikat atau apa yang diputus oleh hakim dianggap benar.

${ }^{5}$ Retnowulan Sutantio, dan Iskandar Oeripkartawinata. Op. Cit.. hal. 83.

${ }^{6}$ Lilik Mulyadi. "Hukum Acara Perdata Menurut Teori dan Praktek Peradilan Indonesia”. (Jakarta: Djambatan. 1998). hal. 149.

${ }^{7}$ Riduan Syahrani. Hukum Acara Perdata Di Lingkungan Peradilan L'mum, (Jakarta: Pustaka Kartini. 1988), hal. 85.

${ }^{8}$ Leden Marpaung. SH. Putusan Bebas Masalah dan Pemecahannya. (Jakarta: Sinar (irafika. 1995). hal. 93. 
Oleh karena itu putusan hakim yang berkekuatan hukum tetap tidak dapat diganggu gugat artinya sudah tertutup kesempatan menggunakan upaya hukum biasa, karena putusan tersebut bersifat mengikat dari putusan itu yang bertujuan untuk menetapkan suatu hasil hubungan antara para pihak yang berperkara atau menetapkan suatu keadaan hukum tertentu.

Dengan demikian akibat hukum dari putusan hukum yang berkekuatan hukum tetap ialah apa yang ada pada suatu waktu telah disesuaikan dan diputus oleh hakim, tidak boleh diajukan lagi kepada hakim. Suatu perkara yang pernah diperiksa dan diputus oleh hakim serta mempunyai kekuatan tetap, maka perkara tersebut tidak perlu diulang lagi karena tidak akan mempunyai akibat hukum.

\section{Tinjauan Tetang Putusan Hakim Yang Telah Memperoleh Kekuatan Hukum Tetap}

Dalam suatu perkara perdata diantara pihak, maka perlu adanya suatu pernyataan yang dapat memberikan suatu keputusan guna mengakhiri suatu sengketa.

Putusan hakim adalah suatu pernyataan yang oleh hakim sebagai pejabat negara yang di beri wewenang untuk diucapkan di persidangan dan bertujuan untuk mengakhiri atau menyelesaikan suatu perkara atau sengketa antara para pihak.

Menurut Lilik Mulyadi SH, Putusan adalah suatu putusan yang di ucapkan oleh hakim karena jabatannya dalam persidangan perkara perdata yang terbuka untuk umum setelah melalui proses dan prosedural Hukum Acara Perdata, pada umumnya dibuat dalam bentuk tertulis dengan tujuan menyelesaikan dan mengakhiri perkara perdata. $^{10}$

Menurut Riduan Syahrani SH, Putusan adalah suatu pernyataan hakim yang diucapkan pada sidang pengadailan yang terbuka untuk umum, untuk menyelesaikan atau mengakhiri perkara perdata. ${ }^{11}$

Dari pendapat diatas maka yang dimaksud dengan putusan hakim yang telah memperoleh kekuatan hukum tetap adalah suatu pemyataan

\footnotetext{
${ }^{9}$ Abdul Kadir Muhammad, Op. Cit., hal.97

${ }^{10}$ Lilik Mulyadi. Op. Cit.. hal. 145.

${ }^{11}$ Riduan Syahrani, Op. Cit., hal. 85.
} 
hakim dalam bentuk tertuiis yang di bacakan dimuka persidangan dengan maksud untuk menyelesaikan atau mengakhiri. Sengketa, maksud dari pemyataan tertuiis yang dibacakan dalam persidangan adalah untuk menghindari agar putusan hakim tidak bembah dan sesuai dengan apa yang diucapkan dalam persidangan sehinga putusan tersebut memperoleh kekuatan hukum tetap.

Dalam KUH Perdata ada beberapa ketentuan tentang putusan hakim yang berkekuatan hukum tetap yaitu pasal 1917 KUH Perdata yang berbunyi :

"Ketentuan suatu putusan hakim yang telah memperoleh kekuatan mutlak tidaklah lebih luas dari pada sekedar mengenai soal putusan, untuk dapat memajukan kekuatan itu perlulah bahwa soal yang dituntut adalah sama, bahwa tuntutan didasarkan atas alas an yang sama. lagi pula dimajukan oleh dan terhadap pihak-pihak yang sama didalam hubungannya yang sama pula".

Menurut Prof. Dr. R.Wirjono Prodjodikoro, S.H., bahwa putusan hakim yang mengandung perintah kepada suatu pihak supaya melakukan suatu perbuatan. Pihak ini dalam putusan hakim dikatakan dihukum untuk ini dan itu. ${ }^{12}$

Jadi pada garis besarnya hakim dalam menjatuhkan putusannya untuk mengakhiri sengketa perdata yang terjadi antara pihak tergugat dan penggugat, dengan dijatuhkan putusan hal ini memberikan konsekuensi kepada hakim agar isi putusannya haras dapat memenuhi rasa keadilan bagi para pihak yang bersangkutan.

Oleh karena itu putusan hakim yang berkekuatan hukum tetap tidak dapat diganggu gugat artinya sudah tertutup kesempatan menggunakan upaya hukum biasa, karena putusan tersebut bersifat mengikat dari putusan itu yang bertujuan untuk menetapkan suatu hasil hubungan antara para pihak yang berperkara atau menetapkan suatu keadaan hukum tertentu.

Dengan demikian akibat hukum dari putusan hukum yang berkekuatan hukum tetap ialah apa yang ada pada suatu waktu telah disesuaikan dan diputus oleh hakim. tidak boleh diajukan lagi kepada hakim. Suatu perkara yang pernah diperiksa dan diputus oleh hakim serta mempunyai kekuatan tetap, maka perkara tersebut tidak perlu

12 Wirjono R Prodjodikoro SH. "Himpunan Peraturan Hukum Acara Perdata di Indonesia ". (Bandung: Sinar Bandung. 1988), hal. 33. 
diulang lagi karena tidak akan mempunyai akibat hukum. 13 Tetapnya putusan hakim adalah merupakan tujuan perkara perdata yaitu untuk menentukan bagaimana akhirnya hubungan hakim antara kedua belah pihak untuk menentukan hukum yang menguasai soal-soal yang menjadi perkara.

Menurut pasal 25 ayat (1) UU No.4 tahun 2004, menjelaskan secara jelas menerangkan bahwa "segala putusan pengadilan selain harus memuat alasan dan dasar putusan tersebut, memuat pula pasal tertentu dari peraturan perundang-undangan yang bersangkutan atau sumber hukum tak tertulis yang dijadikan dasar untuk mengadili".

Selanjutnya dalam pasal 184 HIR ditentukan setiap putusan hakim harus memuat ringkasan yang nyata dari tuntutan dan jawaban serta alas an putusan itu, putusan tentang pokok perkara dan banyaknya ongkos perkara, pemberitahuan tentang hadir tidaknya kedua belah pihak itu pada waktu putusan itu dijatuhkan.

Dari ketentuan pasal tersebut diatas, dapat disimpulkan mengenai perincian isi putusan hakim yangtelah memperoleh kekuatan hukum tetap itu sebagai berikut:

1. Ringkasan Tuntutan

Dalam ringkasan tuntutan penggugat pada pokoknya memuat penjelasan yang singkat tapi jelas tentang apa yang digugatkan atau dituntut, juga memuat keterangan diri dari kedua belah pihak seperti nama, pekerjaan, tempat tinggal dan sebagainya.

2. Jawaban para pihak Dalam Pemeriksaan Perkara

Disini memuat jawaban menurut jalannya kejadian dan hasil pemeriksaan perkara dengan pembuktiannya.

3. Alasan-alasan dan Dasar Putusan

Alasan-alasan ini berupa uraian tentang duduknya perkara atau uraian tentang kejadian-kejadian sebagaimana telah dijelaskan dalam angka I dan 2 diatas.

3. Peraturan Hukum yang Bersangkutan

Di sini memuat pasal-pasal peraturan hukum yang menjadi dasar putusan. Apabila mengadili menggunakan peraturan hukum yang tidak tertulis sebagai dasarnya harus disebutkan sumber hukum tak tertulis itu

4. Putusan tentang Pokok Perkara

Isi putusan pengadilan mengenai pokok perkara itu disebutkan dictum. Dalam dictum ini dimuat suatu pemyataan hukum

${ }^{13}$ Abdul Kadir Muhammad, Op. Cit., hal.105. 
penetapan suatu hak atau hubungan hukum, keadaan hukum tertentu, lenyap atau timbulnya keadaan hukum dan isi putusan yang disebut hukuman yang berupa pembebanan prestasi tertentu. Yang paling penting dalan dictum itu ialah tentang pokok perkara, yaitu yang menjadi pokok perselisihan. Dalam dictum ditetapkan siapa yang berhak atau siapa yang benar atas pokok perselisian itu.

5. Banyaknya Ongkos Perkara

Dalam dictum putusan disebutkan juga banyaknya ongkos perkara dan dibebankan pada siapa, penggugat atau tertgugat, atau keduaduanya, menurut ketentuan pasal 182 HIR-193 R.Bg ongkos perkara meliputi biaya kantor panitera pengadilan, ongkos materai, ongkos saksi, ongkos sumpah, ongkos pemeriksaan ditempat, honorarium, juru sita, honorarium panitera atau pejabat lainnya yang menjalankan putusan hakim, pelaksanaan sita jaminan. Semuanya itu telah ditetapkan dalam peraturan oleh menteri kehakiman.

6. Hadir tidaknya Kedua Belah Pihak

Dalam pemeriksaan perkara dipersidangan, mungkin penggugat atau tergugat atau kedua-duanya tidak hadir. Demikian juga pada waktu hakim mengucapkan putusannya. Apabila penggugat atau tergugat tidak hadir pada sidang pertama, maka dalam putusan hakim haras disebutkan dan ini erat hubungaimya dengan penetapan siapa yang dibebani membayar ongkos pertama. Apabila penggugat atau tergugat atau kedua belah pihak tidak hadir pada waktu hakim mengucapkan putusannya, maka dalam putusan haras disebutkan ketidak hadirannya itu.Hal ini erat hubungannya dengan pemberitahuan putusan tersebut kepada yang bersangkutan terutama pada tergugat.

7. Tandatangan Hakim dan Panitera

Setiap putusan pengadilan haras ditandatangani oleh Ketua, Hakim-hakim anggota yang menulis perkara itu, dan panitera yang ikut bersidang. Dengan tandatangan mereka itu,surat putusan tersebut menjadi akta otentik. Disamping itu juga melukiskantanggung jawab hakim-hakim yang memutus perkara itu. Di bawah tandatangan mereka itu disebutkan juga pertelaan ongkos perkara dan jumlahnya. 


\section{Kekuatan Mengikatnya Putusan Hakim yang Telah Memperoleh Kekuatan Hukum Tetap.}

Putusan yang sudah menjadi tetap tidak dapat diganggugugat, artinya sudah tertutup kesempatan menggunakan upaya hukum biasa untuk melawan putusan itu, karena tenggang waktu yang ditentukan UU sudah lampau. Putusan yang sudah menjadi tetap memperoleh kekuatan pasti yang bersifat mengikat Dalam peribahasa hukum dikatakan "res judicata proveritate habitur". Artinya putusan yang pasti dengan sendirinya mengikat. Apa yang diputus oleh hakim dianggap benar dan pihak-pihak berkewajiban untuk memenuhi putusan tersebut. Dalam bagian pernyataan itulah ditetapkan suatu hak atau hubungan hukum, atau suatu keadaan hukum tertentu atau lenyapnya suatu keadaan hukum tertentu.

Akibat dari kekuatan mengikat suatu putusan itu ialah apa yang pada suatu waktu telah diselesaikan dan diputus oleh hakim tidak boleh diajukan lagi kepada hakim. Kepastian dari putusan hakim adalah prinsip umum yang diakui dalam dunia peradilan. Apabila suatu perkara sudah pernah diperiksa dan diputus oleh hakim dan telah memperoleh kekuatan pasti yang bersifat mengikat, perkara yang demikian itu dapat diulangi lagi karena tidak akan memperoleh akibat hukum.

Menurut Soepomo putusan hakim yang sudah menjadi tetap dapat digunakan secara positif apabila penggugat mendasarkan tuntutannya pada putusan hakim. Dapat digunakan secara negatif apabila apabila tergugat menolak tuntutan dengan alasan, tuntutan itu telah pernah diputus oleh hakim. ${ }^{14}$

Walaupun pada prinsipnya hakim tidak mempunyai keharusan mengikuti putusan yang pernah dijatuhkan, Namun apabila menurut pertimbangannya adalah layak untuk memperhatikan putusan tersebut, ia dapat mendasarkan putusannya yang sudah menjadi tetap itu. Tetapi apabila perkara yang diajukan itu adalah perkara yang tidak pernah diputus dan memperoleh kekuatan pasti, hakim tidak lain harus menolak perkara tersebut.

Jadi putusan hakim mempunyai kekuatan mengikat yaitu mengikat kedua belah pihak. Terikatnya para pihak kepada putusan,

${ }^{14}$ Supomo R, Hukum Acara Perdata Pengadilan Negeri, Pradya Paramita: Jakarta, 1989, hal. 57. 
menimbulkan beberapa teori yang hendak mencoba memberi dasar tentang kekuatan mengikat dari pada putusan, yaitu:

\section{Teori Hukum Materiil}

Menurut teori ini Maka kekuatan mengikat dari pada putusan yang lazimnya disebut " gezag van gewijsde " mempunyai sifat hukum materiil oleh karena mengadakan perubahan terhadap wewenang dan kewajiban keperdataan : Menetapkan, Menghapuskan atau mengubah. Menurut teori ini putusan itu dapat menimbulkan atau meniadakan hubungan hukum. Jadi putusan merupakan sumber hukum materiil. Suatu tuntutan pembayaran atau pelunasan hutang dari penggugat yang dikabulkan oleh pengadilan yang menyebabkan penggugat menjadi kreditur, Sekalipun putusannya belum tentu benar. Demikian pula kalau pengadilan mengabulkan tuntutan tentang hak milik, maka karena putusan tersebut penggugat menjadi pemilik.

Disebut sebagai ajaran hukum materiil karena memberi akibat yang bersifat hukum materiil pada putusan. Mengigat bahwa putusan itu hanya mengikat para pihak dan tidak mengikat pihak ketiga, kiranya teori ini tidaklah tepat. Ajaran ini tidak memberi wewenang untuk mempertahankan hak seseorang terhadap pihak ketiga.

\section{A. Teori Hukum Acara}

Menurut teori ini putusan bukanlah sumber hukum materiil, melainkan sumber dari pada wewenang prosesuil. Siapa yang dalam suatu putusan diakui sebagai pemilik, maka ia dengan sarana prosesuil terhadap lawannya dapat bertindak sebagai pemilik. Baru apabila undang-undang mensyaratkan adanya putusan itu timbulnya keadaan hukum baru, maka putusan itu mempunyai arti hukum materiil. Akibat putusan itu bersifat hukum acara, yaitu diciptakannya atau dihapuskannya wewenang dan kewajiban prosesuil. Ajaran ini sangat sempit, sebab suatu putusan bukanlah semata-mata hanyalah sumber wewenang prosesuil, karena menuju pada penetapan yang pasti tentang hubungan hukum yang merupakan pokok sengketa.

\section{B. Teori Hukum Pembuktian}

Menurut teori ini putusan merupakan bukti tentang apa yang ditetapkan didalamnya, sehingga mempunyai kekuatan mengikat oleh karena itu menurut teori ini pembuktian lawan terhadap isi suatu putusan yang telah memperoleh kekuatan hukum yang pasti tidak 
diperkenankan. Teori ini termasuk teori kuno yang sudah tidak banyak penganutnya.

\section{Terikatnya para Pihak pada Putusan}

Terikatnya para pihak kepada putusan dapat mempunyai arti positif dan dapat pula mempunyaiarti negatif.

Arti Positif:

Arti positif dari kekuatan mengikat suatu putusan adalah bahwa apa yang telah diputus diantara para pihak berlaku sebagai positif benar. Apa yang telah diputus oleh hakim harus dianggap benar: res judicata proveritate habetur. Pembuktian lawan tidak dimungkinkan.

Arti Negatif:

Arti negatif dari kekuatan mengikat suatu putusan adalah bahwa hakim tidak boleh memutus perkara yang pernah diputus sebelumnya antara pihak yang sama serta mengenai pokok perkara yang sama.

\section{Kekuatan Hukum yang Pasti}

Suatu putusan memperoleh kekuatan hukum yang pasti atau tetap (kracht van gewijsde ) apabila tidak ada lagi upaya hukum biasa tersedia. Upaya hukum biasa ialah Perlawanan, banding dan kasasi. Dengan memperoleh kekuatan hukum yang pasti maka putusan itu tidak lagi dapat diubah, sekalipun oleh pengadilan yang lebih tinggi, kecuali dengan upaya hukum yang khusus, yaitu request civil dan perlawanan oleh pihak ketiga.

Penulis berpendapat bahwa suatu putusan mempunyai kekuatan mengikat yang negatif kalau belum mempunyai kekuatan hukum yang pasti dan sejak mempunyai kekuatan hukum yang pasti memperoleh kekuatan mengikat yang positif Menurut pendapat penulis, maka putusan yang belum memperoleh kekuatan hukum yang pasti sudah mempunyai kekuatan mengikat yang positif. Putusan yang telah dijatuhkan harus dianggap benar dan sejak diputuskan para pihak harus menghormati dan mentaati.

Suatu putusan itu terdiri dari bagian yang merupakan dasar dari putusan dan bagian yang merupakan putusan itu sendiri atau yang lazim disebut sebagai amar dictum 
Suatu Putusan Hakim sekalipun terdiri dari dasar putusan dan dictum, namun merupakan suatu kesatuan, sehingga kekuatan mengikat dari putusan itu pada umumnya tidak terbatas pada dictum saja, tetapi meliputi juga dari bagian dari putusan yang merupakan dasar putusan.

Kekuatan mengikat dari putusan itu tidak meliputi penetapanpenetapan mengenai peristiwa. Apabila hakim dalam suatu putusan telah mengconstair suatu peristiwa tertentu berdasarkan alat-alat bukti tertentu, maka dalam sengketa lain peristiwa tersebut masih disengketakan.

Oleh siapakah dan terhadap siapakah kekuatan mengikat dari putusan itu dapat diajukan?

Telah diketengahkan dimuka pada asasnya Putusan hakim hanyalah mengikat para pihak (Pasal 1917 BW). Yang dimaksud dengan pihak bukanlah hanya penggugat dan tergugat saja, tetapi juga pihak ketiga yang ikut serta dalam sengketa antara penggugat dan tergugat, baik dengan jalan interventie maupun pembebasan (vrijwaring) atau mereka yang diwakili dalam proses. Mahkamah Agung dalam putusannya Tanggal 9 November 1955 berpendapat bahwa suatu putusan hakim tidak hanya mempunyai kekuatan terhadap pihak yang kalah, melainkan juga terhadap seseorang yang kemudian mendapat hak dari pihak yang kalah.

Jadi putusan dapat mengajukan atau menggunakan kekuatan mengikat dari putusan adalah para pihak.

Terhadap pihak ketiga putusan tidak mempunyai kekuatan mengikat, Tetapi pihak ketiga ini dapat mengajukan perlawanan terhadap putusan yang telah mempunyai kekuatan hukum yang pasti (Pasal $378 \mathrm{Rv}$ ). Dalam hal ini perlu mendapat perhatian bahwa pihak ketiga yang dirugikan oleh putusan itulah yang dapat mengajukan perlawanan.

\section{Proses atau Tahap-Tahap Dalam Pengajuan Upaya Hukum Peninjauan Kembali}

Proses pengajuan upaya hukum peninjauan kembali menurut Pasal 2 UU No.1 Tahun 1980 Tentang Peninjauan Kembali Putusan yang telah memperoleh kekuatan hukum tetap yaitu :

1. Permohonan peninjauan kembali suatu putusan perdata yang telah memperoleh kekuatan hukum yang tetap harus diajukan sendiri 
oleh pihak yang berkepentingan termasuk ahli warisnya atau seorang wakilnya yang secara khusus dikuasakan.

2. Permohonan diajukan secara tertulis dengan menyebutkan sejelasjelasnya alasan yang dijadikan dasar permohonan itu dan dimasukkan diKepaniteraan Pengadilan Negeri yang bersangkutan dengan perkara tersebut atau diajukan langsung ke Mahkamah Agung.

3. Apabila pemohon tidak dapat menulis, maka ia menguraikan permohonannya secara lisan dihadapan Ketua Pengadilan Negeri tersebut atau Hakim yang ditunjuk olehnya, yang akan memuat catatan tentang pennohonan itu.

4. Pengadilan tersebut segera mengirimkan surat pennohonan atau catatan tentang permohonan lisan itu beserta berkas perkaranya kepada Ketua Mahkamah Agung.

Sedangkan Proses dalam pengajuan upaya hukum peninjauan kembali Menurut Soedirjo, S.H, yaitu: ${ }^{15}$

5. Dimulai dengan diterimanya permohonan peninjauan kembali secara tertulis atau dengan lisan di Kepaniteraan Pengadilan Negeri yang pemah memutus perkara tersebut.

6. Untuk pemohon peninjauan kembali dikenakan pembayaran biaya perkara yang dibayarnya ketika memasukan permohonannya di Kepaniteraan.

7. Untuk itu penerima permohonan peninjauan kembali serta biaya perkara itu panitera memberikan tanda penerimaan yang berisi hari dan tanggai diterimanya peraiohonan dan biaya itu.

8. Tanggal penerimaan permohonan itu penting untuk menghitung tenggang waktu pengajuan peninjauan kembali.

Setelah pengadilan negeri menerima suatu peramohonan peninjauan kembali, maka panitera secepatnya memberikan atau mengirimkan salinan permohonan kepada pihak lawan dari pemohon dengan maksud:

a. Bilamana hal itu mengenai permohonan peninjauan kembali yang didasarkan atas alasan sebagaimana dimaksud dalam pasal 67 UU No. 14 Tahun 1985, supaya ada kesempatan baginya untuk mengajukan jawabannya.

15 Soedirjo, "Peninjauan Kembali Dalam Perkara Perdata Arti dan Makna", Akademika Presindo, Jakarta, 1986, hal. 73-74. 
b. Bilamana hal itu mengenai permohonan peninjauan kembali yang didasarkan atas alasan sebagaimana dimaksud dalam pasal 67 UU No. 14 Tahun 1985, supaya dimaklumi.

Pihak lawan yang menerima salinan permohonan peninjauan kembali berdasarkan alasan dari pasal 67 UU No. 14 Tahun 1985 tersebut dapat mengajukan jawabannya dalam waktu 30 hari dihitung sejak tanggal diterimanya tuntutan surat permohonan peninjauan kembali tersebut.

Surat jawaban diserahkan atau dikirimkan kepada Pengadilan Negeri tersebut dan pada surat jawaban tersebut oleh panitera dibubuhi cap yang berisi hari serta tanggal diterimanya jawaban tersebut yang tuntutannya disampaikan atau dikirimkan kepada pemohon peninjauan kembali untuk dimaklumi seperlunya.

Kemudian permohonan jawaban atas permohonan serta surat-surat bukti dan bahan bukti lain kalau ada, lengkap dengan berkas perkara beserta biaya perkara diteruskan atau dikirimkan ke Mahkamah Agung dengan cara yang tercepat dan teraman.

Setelah seluruh berkas perkara diterima Mahkamah Agung maka diadakan regestrasi dalam buku daftar perkara, untuk itu dan sesudah itu diadakan pemilihan apakah syarat-syarat kelengkapan berkas dipenuhi. Atas penerimaan pengiriman berkas itu direktorat/bidang perdata kepaniteraan Mahkamah Agung mengirimkan tanda terima kepada pengadilan negeri yang bersangkutan dan kepada pihak-pihak turunannya.

Ketua Mahkamah Agung menentukan Hakim-Hakim yang membentuk suatu Majelis untuk memeriksa dan memutuskan perkara permohonan peninjauan kembali. Apabila Hakim Majelis telah mempelajari berkas perkara dan pemeriksaan dipandangnya sudah cukup, maka diadakan musyawarah untuk mengambil putusan.

Mahkamah Agung adalah Pengadilan Negara Tertinggi dari semua Lingkungan Peradilan, yang dalam melaksanakan tugasnya terlepas dari pengaruh pemerintah dan pengaruh-pengaruh lain.

\section{A. Pertimbangan Hakim Dalam Memutuskan Putusan Peninjauan Kembali Terhadap Putusan Yang Telah Memperoleh Kekuatan Hukum Tetap}

Bahwa negara Republik Indonesia, sebagai negara hukum yang berdasarkan Pancasila dan Undang-Undang Dasar 1945, bertujuan mewujudkan tata kehidupan bangsa yang sejahtera, aman, tenteram dan tertib.

Bahwa dalam mewujudkan tata kehidupan tersebut dan menjamin persamaan kedudukan warga negara dalam hukum diperlukan upaya 
untuk menegakkan ketertiban, keadilan, kebenaran, dan kepastian hukum yang mampu memberikan pengayoman kepada masyarakat.

Terutama dalam upaya hukum peninjauan kembali, bahwa untuk melaksanakan upaya hukum peninjauan kembali ini, terlebih dahulu perkara yang diajukan harus sudah mempunyai kekuatan hukum tetap, Upaya hukum peninjauan kembali merupakan upaya tingkat terakhir setelah pengadilan negeri, banding, kasasi, karena apabila putusan itu belum mempunyai kekuatan hukum tetap maka putusan itu tidak dapat diterima dan tidak dapat diajukan peninjauan kembali.

Suatu putusan memperoleh kekuatan hukum tetap apabila tidak ada lagi upaya hukum biasa yang tersedia. Dengan memperoleh kekuatan hukum yang pasti maka putusan itu tidak lagi dapat diubah, sekalipun oleh pengadilan yang lebih tinggi, kecuali dengan upaya hukum yang khusus yaitu peninjauan kembali. ${ }^{16}$

Pertimbangan dalam putusan perdata dibagi dua yaitu pertimbangan tentang duduknya perkara atau peristiwanya dan pertimbangan tentang hukumnya. Adapun pertimbangan yang dibuat dari putusan tidak lain adalah alasan-alasan hakim sebagai pertanggung jawab kepada masyarakat, mengapa sampai mengambii putusan yang sedemikian sehingga mempunyai nilai yang obyektif.

Alasan dasar putusan harus dimuat dalam pertimbangan putusan. Bahwa setiap putusan harus memuat ringkasan yang jelas dari tuntutan dan jawaban, alasan dan dasar dari pada putusan, pasal-pasal serta hukum tidak tertulis, pokok perkara, biaya perkara serta hadir tidaknya para pihak, pada waktu putusan diucapkan oleh hakim.

Permohonan untuk memeriksa dan memutus sengketa kewenangan mengadili dalam perkara perdata, diajukan secara tertulis kepada Mahkamah Agung disertai pendapat dan alasannya oleh:

a. Pihak yang berperkara melalui Ketua Pengadilan;

b. Ketua Pengadilan yang memeriksa perkara tersebut.

\section{B. Hambatan Dalam Proses Peninjauan Kembali Terhadap Putusan yang Telah Memperoleh Kekuatan Hukum Tetap.}

Apabila dalam pengajuan permohonan peninjauan kembali itu tidak langsung diajukan langsung ke Mahkamah Agung itu juga akan menjadi permasalahan, karena sudah dijelaskan bahwa dalam mengajukan permohonan peninjauan kembali harus didasarkan pada

${ }^{16}$ Sudikno Mertokusumo, Op. Cit., hal. 26. 
syarat-syarat peninjauan kembali, sehingga prosesnya akan menjadi lancar dan tidak ada hambatan.

Bahwa proses peninjauan kembali itu sudah diatur dalam perundang-undangan, jadi para pemohon peninjauan kembali dalam melakukan permohonan harus sesuai dengan prosedur dan tata cara yang sudah ditetapkan.

Bahwa hambatan atau masalah yang biasa terjadi didalam proses peninjauan kembali adalah terlalu lamanya berkas perkara yang ada dalam Mahkamah Agung, sehingga proses pelaksanaannya menjadi terhambat. Akan tetapi hambatan seperti itu bukan merupakan hambatan yang tehnis dalam pengambilan putusan.

Berdasarkan hasil wawancara penulis dengan Ibu Maya, $\mathrm{SH},{ }^{17}$ selaku hakim Pengadilan Negeri Surakarta, beliau menjelaskan bahwa sebenarnya dalam pelaksanaan peninjauan kembali itu, hambatan maupun permasalahannya hanya terletak pada pemohon peninjauan kembali. Dimana beliau menjelaskan adanya kekurangan ataupun kelemahan peninjauan kembali, menurutnya kekurangan peninjauan kembali adalah bahwa terdapat dalam syarat untuk mengajukan pengambilan keputusan, dimana permohonan pengambilan putusan dapat dicabut kembali tidak menangguhkan atau menghentikan pelaksanaan putusan pengadilan dan permohonan peninjauan kembali dapat dicabut selama belum diputus dan dalam hal ini permohonan yang sudah dicabut tidak dapat diajukan lagi.

Bahwa sebenarnya hambatan ataupun masalah dalam proses pelaksanaan peninjauan kembali tersebut hanya didasarkan pada ada tidaknya alasan atau benar tidaknya alasan yang diajukan dalam pengajuan permohonan peninjauan kembali.

Bahwa peninjauan kembali hanya dapat dipakai atas kekhilafan terhadap fakta. Pokok permasalahan dalam peninjauan kembali adalah mengadakan koreksi terhadap suatu putusan yang dalam satu segi tidak sesuai, tidak tepat, sebab fakta-fakta yang dijadikan dasar putusan hakim tidak memenuhi syarat.

Proses peninjauan kembali itu memenuhi syarat-syarat yang ada dalam perundangan yaitu tentang diterima tidaknya permohonan kembali. Bahwa dalam pengajuan permohonan peninjauan kembali, si pemohon harus memperhatikan syarat-syarat peninjauan kembali yaitu

${ }^{17}$ Wawancara langsung dengan Ibu Maya. SH. Selaku Hakim di Pengadilan Negeri Surakarta. Tanggal 25 Agustus 2005. 
dengan melihat alasan-alasan yang ada dalam perundang-undangan, sehingga permohonannya dapat diterima.

Sedangkan apabila permohonan peninjauan kembali tidak memenuhi syarat-syarat tersebut maka permohonannya tidak akan diterima, diantaranya adalah:

1) Permohonan peninjauan kembali telah melampaui tenggang waktu.

2) Permohonan yang diajukan tidak terdapat hal-hal atau alasan dalam UU No. 14 tahun 1985.

Dalam pemeriksaan permohonan peninjauan kembali pertamatama dilihat masalah dapat diterima atau tidaknya permohonan sebagai dasar pemeriksaan. Apabila permohonan memenuhi syarat-syarat peninjauan kembali maka barulah Mahkamah Agung memasuki materi perkara peninjauan kembali.

Dalam kaitannya kasus permohonan peninjauan kembali itu, maka putusan Mahkamah Agung dapat dibedakan atas:

1) Putusan yang menyatakan permohonan peninjauan kembali tidak dapat diterima.

2) Putusan yang menolak dan;

3) Putusan yang mengabulkan permohonan peninjauan kembali.

Suatu permohonan peninjauan kembali dapat diterima sebagai dasar pemeriksaan (onvant kelijk) yaitu:

a. Apabila diajukan oleh pihak berkepentingan yang diperkara atau ahli warisnya atau wakilnya berdasarkan surat kuasa khusus.

b. Apabila diajukan terhadap putusan yang telah mendapat kekuatan hukum tetap.

c. Apabila diajukan berdasarkan alasan-alasan sebagaimana dimaksud dalam pasal 67 UU No 14 Tahun 1985.

d. Apabila diajukan dalam tenggang waktu enam bulan sebagaimana ditentukan dalam UU No 14 Tahun 1985.

Apabila syarat-syarat itu tidak dipenuhi maka permohonan peninjauan kembali dinyatakan tidak dapat diterima oleh Mahkamah Agung. Permohonan peninjauan kembali tidak dapat diterima apabila:

1) Permohonan diajukan tidak pada Mahkamah Agung.

2) Permohonan diajukan kepada orang yang tidak merupakan pihak dalam perkara semula. 
3) Permohonan tidak berdasarkan atas alasan-alasan sebagaimana dimaksud dalam pasal 67 UU No 14 Tahun 1985.

4) Diajukan terhadap putusan yang belum mempunyai kekuatan hukum tetap.

5) Diajukan tidak dalam tenggang atau jangka waktu.

6) Diajukan oleh seorang wakil tanpa surat kuasa khusus.

7) Diaujukan untuk kedua kalinya.

Namun dari hasil penelitian yang telah penulis lakukan pada putusan peninjauan kembali, Mahkamah Agung telah memutuskan dan mengabulkan gugatan penggugat, karena permohonan yang diajukan oleh pemohon peninjauan kembali telah sesuai dengan syarat-syarat peninjauan kembali. Maka permohonan yang diajukan oleh penggugat dapat dikabulkan oleh Mahkamah Agung.

Adapun hasil putusan yang diambil oleh Mahkamah Agung dalam memutuskan perkara peninjauan kembali antara Penggugat dan Tergugat, bahwa Mahkamah Agung telah menerima dan mengabulkan permohonan pengambilan putusan dari Penggugat, dan membatalkan putusan Mahkamah Agung yang membatalkan putusan Pengadilan Tinggi Semarang.

Putusan yang telah diambil oleh Mahkamah Agung sebagai hakim dalam perkara peninjauan kembali itu sesuai dengan alasan-alasan yang ada dalam perkara yang diajukan oleh pemohon peninjauan kembali. Alasan-alasan tersebut telah sesuai dengan syarat-syarat ataupun alasan yang ada dalm pasal 67 UU No 14 Tahun 1985.

Bahwa hakim dalam memutus perkara peninjauan kembali ini dengan melihat atau berdasarkan pada alasa-alasan tersebut. Jadi apabila hakim melihat perkara yang diajukan peninjauan kembali itu tidak ada atau tidak memuat salah satu dari alasan itu maka Mahkamah Agung akan menolak permohonan peninjauan kembali, namun apabila dalam perkara yang diajukan itu ada alasan-alasan yang terdapat dalam pasal 67 UU No 14 Tahun 1985, maka Mahkamah Agung akan mempertimbangkan putusan itu. Setelah hakim mempertimbangkan semua putusan dalam perkara itu kemudian hakim membuat keputusan yang pada intinya untuk menerima atau menolak putusan peninjauan kembali tersebut Akan tetapi dalm kasus ini hakim telah menjatuhkan putusannya dengan mengabulkan permohonan peninjauan kembali.

Dalam hal memutuskan atau melaksanakan proses peninjauan kembali itu hakim sama sekali tidak mengalami suatu hambatan apapun, karena si pemohon peninjauan kembali dalam mengajukan 
permohonannya telah benar dan sesuai dengan tata cara atau proses peninjauan kembali.

\section{Penutup}

Bahwa proses peninjauan kembali dimulai dengan diterimanya permohonan peninjauan kembali secara tertulis ataupun dengan lisan dikepaniteraan Pengadilan Negeri yang telah memutuskan perkaranya dalam tingkat pertama. Setelah pengadilan negeri menerima suatu permohonan peninjauan kembali, maka panitera memberikan atau mengirimkan salinan putusan Pengadilan Negeri yang telah memperoleh kekuatan hukum tetap ke Mahkamah Agung. Setelah seluruh berkas putusan diterima Mahkamah Agung, kemudian Mahkamah Agung meneliti putusan Pengadilan Negeri yang telah memperoleh kekuatan hukum tetap itu, apakah ada alasan-alasan yang ditolak atau diterima. Diterimanya putusan oleh Mahkamah Agung untuk diperiksa terdapat unsur kekeliruan yang disebabkan karena kebohongan atau tipu muslihat sebagaimana yang dimaksud dalam Pasal 67 Undang-Undang No.14 Tahun 1985, setelah itu putusan peninjauan kembali tersebut dikuatkan oleh Mahkamah Agung. Apabila putusan Pengadilan Negeri yang telah memperoleh kekuatan hukum tetap ditolak Mahkamah Agung karena tidak terdapat alasan-alasan yang sesuai dengan pasal tersebut diatas, maka Mahkamah Agung menguatkan putusan Pengadilan Negeri. Kemudian Mahkamah Agung, mengirimkan putusan tersebut langsung kepada pihak pemohon peninjauan kembali.

Bahwa pertimbangan yang diambil hakim dalam memutuskan perkara peninjauan kembali seperti dalam contoh kasus warisan adalah dengan melihat adanya dua alasan yang terdapat dalam permohonan yang diajukan peninjauan kembali tersebut. Adapun dua alasan itu adalah ditemukannya bukti baru yang belum peniah diajukan pada persidangan sebelumnya, yaitu bukti peninjauan kembali 1 dan peninjauan kembali 2, kedua bukti tersebut membuktikan bahwa penggugat dan tergugat menolak warisan dari almarhum ayah/kakek mereka, sehingga mereka-mereka tidak perlu lagi dijadikan subyek hukum dalam perkara ini, sedangkan alasan yang kedua adalah mengenai suatu bagian dari tuntutan belum diputus tanpa dipertimbangkan sebab-sebabnya. Bahwa Mahkamah Agung dalam putusan kasasinya yang telah membatalkan putusan Pengadilan Tinggi tanpa memberikan pertimbangan yang jelas dan tanpa menyebutkan sebabsebabnya.

Hambatan atau masalah yang terjadi dalam melaksanakan peninjauan kembali terhadap putusan yang telah memperoleh kekuatan hukum tetap, 
sebenarnya secara teknis tidak terjadi hambatan maupun masalah dalam pelaksanaan peninjauan kembali terhadap perkara ini. Biasanya dalam pelaksanaan peninjauan kembali hanya ada kekurangan ataupun kelemahan yang dilakukan oleh pemohon peninjauan kembali sendiri. Adapun kekurangan dan kelemahan itu terdapat dalam syarat untuk mengajukan permohonan peninjauan kembali, yaitu dalam mengajukan permohonan Peninjauan kembali harus sesuai dengan alasan-alasan peninjauan kembali, sehinga Mahkamah Agung dalam mengambil keputusan dapat berjalan dengan lancar dan baik. 


\section{Daftar Pustaka}

Abdulkadir, Muhammad, Hukum Acara Perdata, Bandung: Alumni, 1986.

Amirudin, dan Zainal Asikin., Pengantar Metodelogi Penelitian Hukum, Jakarta: PT. Raja grafindo Persada, 2004.

Djazuli, Bachar., Eksekusi Putusan Perkara Perdata Segi Hukum dan Penegak Hukum, Bandung: Akademika Pressindo, 2001.

Husein, Harun M. 1992, Kasasi Sebagai Upaya Hukum. Jakarta: Sinar Grafika.

Marpaung, Leden., Perumusan Memori Kasasi dan Peninjauan Kembali Perkara Pidana, Jakarta: Sinar Grafika, 2000.

Mertokusumo, Sudikno., Hukum Acara Perdata Indonesia, Yogyakarta: Liberty, 1988.

Mulyadi, Lilik., Hukum Acara Perdata Menurut Teori dan Praktek Peradilan Indonesia, Jakarta: Djambatan, 1998.

Tresno, R., Komentar HIR, Jakarta: PT. Paramita, 1996.

Sulistini, Elise T., dan Rudy T Erwin., Petunjuk Praktis Menyelesaikan Perkara-Perkara Perdata, Jakarta: Bina Aksara, 2000.

Supranto, J., Metodologi Penelitian Hukum dan Statistik, Jakarta: PT. Rineka Cipta, 2003.

Syahrani, Riduan., Hukum Acara Perdata di Lingkungan Peradilan Umum, Jakarta: Pustaka Kartini, 1998.

, SH, 1991, Himpunan Peraturan Hukum Acara Perdata Indonesia, Bandung, Alumni.

Subekti., Hukum Acara Perdata. Jakarta: Bina Cipta, 1982.

Soedirjo., Peninjauan Kembali dalam perkara Perdata, Jakarta: Akademika Pressindo, 1986.

Soepomo., Hukum Acara Perdata Pengadilan Negeri. Jakarta: PT. Pradnya Paramita, 1989.

Wirjono R. Prodjodikoro, Hukum Acara Perdata di Indonesia, Bandung: PT. Sinar Grafika, 1988.

, Undang-undang Nomor 4 tahun 2004 Tentang Pokok-pokok Kekuasaan Kehakiman, Jakarta: Sinar Grafika, 2004. 